\title{
Variant effects of arsenic compounds on crude oil bioremediation by crude oil-degrading bacteria in Kuwait
}

\author{
K. Majki, S. Moustafa, A. S. Al-Dousari \& E. Al-Saleh \\ Microbiology Program, Department of Biological Sciences, \\ Faculty of Science, Kuwait University, Kuwait
}

\begin{abstract}
Crude oil spills into the environment such as that of Kuwait cause health and ecological problems which necessitates the cleanup of such pollution by efficient methods such as bioremediation. However, the associated heavy metals such as arsenic with crude oil pollution exert inhibitory effects on bioremediating agents for instance soil microbiota leading to hindered bioremediation. In the current study, the tolerance of two dominant crude oil-degrading bacteria in Kuwaiti soil, Acinetobacter spp. a Gram-negative bacteria and Nocardia spp. a Grampositive bacteria, to varying concentrations of arsenate and arsenite was investigated. Results showed the higher potentials of Nocardia spp. to resist the inhibitory effects of added arsenic compounds. Also, arsenite demonstrated significantly higher inhibitory effects on bacterial growth and activity compared to those of arsenate. Additionally, determination of the crude oil mineralization potentials of isolated bacteria demonstrated the significantly higher potentials of Nocardia spp. to mineralize crude oil in presence of arsenic compounds. Moreover, the phylogenetic assessment of isolated strains of Acinetobacter and Nocardia using 16S-RFLP analyses showed the higher diversity of Nocardia strains compared to Acinetobacter. Thus, this study demonstrated the variant effects of arsenic species on the growth and activity of different crude oil-degrading bacteria. Also, results indicated that, the potential of crude oildegrading bacteria to tolerate the inhibitory effects of heavy metals, such as arsenic, could accelerate the bioremediation of crude oil pollution.

Keywords: Crude oil-degrading bacteria, Gram-negative bacteria, Grampositive bacteria, Acinetobacter spp., Nocardia spp., arsenite, arsenate.
\end{abstract}




\section{Introduction}

Crude oil contamination is a worldwide continuous problem especially to oilexporting countries such as Kuwait. Oil spills both deliberate and accidental [1] have the tendency to affect human health [2] and ecological niches [3]. Thus, bioremediation is highly required for such polluted environments and considered an excellent approach for cleaning-up crude oil pollution [4] via the indigenous microbiota that in general are sequentially exposed to a variety of pollutants [5]. Usually crude oil pollution is associated with heavy metals contamination, in particular arsenic [6-8]. In nature arsenic occurs in four oxidation states: (-3) in the form of arsenides, arsine $\left(\mathrm{AsH}_{3}\right)$ and arsenic chloride $\left(\mathrm{AsCl}_{3}\right)$; (0) in the form of native arsenic; $(+3)$ in the form of oxides, sulfides, sulfo-salts, and arsenite, and $(+5)$ in the form of arsenate [9]. Arsenic exerts severe toxic effects to all forms of organisms [10], and as a result it was ranked as number one on the Environmental Protection Agency (EPA) list of toxic metals [11]. However, scarce studies are available on the effects of arsenic compounds on hydrocarbon biodegradation potentials of the soil microbiota [12]. Therefore, the growth, activity, diversity and tolerance of two dominant crude oil-degrading bacteria (CODB) in Kuwaiti soil, Acinetobacter spp. [13, 14] a Gram-negative bacteria and Nocardia spp. $[15,16]$ a Gram-positive bacteria to varying concentrations of arsenate and arsenite were investigated in the current study.

\section{Materials and methods}

\subsection{Effect of arsenate and arsenite on the growth of the CODB Acinetobacter spp. and Nocardia spp.}

The potential inhibitory effects of arsenic compounds (arsenate and arsenite) on the growth of the CODB Acinetobacter spp. and Nocardia spp. were determined using the well diffusion method and optical density measurements.

\subsubsection{Agar well diffusion method}

The method of (Lertcanawanichakul and Sawangnop [17]) was adopted. Stocked bacterial cultures were streaked on NA plates and incubated at $30^{\circ} \mathrm{C}$ for 24 hours. Grown bacterial cultures were transferred into sterile $15 \mathrm{ml}$ Falcon tubes containing sterile $0.85 \% \mathrm{NaCl}$ solution followed by adjusting the number of bacterial cells to $1.2 \times 10^{9}$ cells $^{-1} \mathrm{ml}$ using McFarland No.0.5 as a standard solution. Then, aliquots $(100 \mu \mathrm{l})$ of the prepared bacterial suspension were spread on the surface of NA plates, spread evenly and left for $30 \mathrm{~min}$ at room temperature. Then, wells (10 $\mathrm{mm}$ in diameter) were punched using sterile stainless steel cork borer. Prepared metal $\left(\mathrm{As}^{+5}, 50 \mathrm{mg}^{-1} \mathrm{ml}\right.$ and $\mathrm{As}^{+3}, 5 \mathrm{mg}^{-1} \mathrm{ml}$ ) solutions were directly filled $(50 \mu \mathrm{l})$ into the wells, plates incubated at $30^{\circ} \mathrm{C}$ for 24 hours and the diameter of the inhibition zones were measured in millimeter [17]. 


\subsubsection{Optical density measurements}

Prepared bacterial suspensions used for the well diffusion method mentioned previously were used simultaneously for the optical density measurement method. For this purpose, bacterial suspension $(50 \mu \mathrm{l})$, sterile nutrient broth $(50 \mu \mathrm{l})$ and different concentrations of arsenate and arsenite solutions (300 $\mu \mathrm{l})$ were transferred to 100 -well Honeycomb plates. Then, plates were incubated shaking at $30^{\circ} \mathrm{C}$ for 24 hours in automated optical density reader $(600 \mathrm{~nm})$. Determined optical density values were plotted against time followed by calculation of bacterial growth rates. Bacterial growth rates were used to determine the minimum inhibitory concentrations (MIC) for tested metals. MIC values were defined as the lowest concentration of tested metals that inhibited the growth of bacteria after 24 hours of incubation.

\subsection{Effect of arsenic compounds on the activity of the CODB Acinetobacter spp. and Nocardia spp.}

The inhibitory effects of arsenate and arsenic on the activities of the CODB Acinetobacter spp. and Nocardia spp. were determined. For this purpose, the activity of the dehydrogenase and the rate of carbon dioxide evolution were used as indicators for bacteria activity under different carbon sources and metal concentrations.

\subsubsection{Determination of dehydrogenase activity}

The method of (Alef [18]) was adopted. Overnight grown bacterial cultures on nutrient broth were harvested at $4200 \mathrm{xg}$ in sterile $50 \mathrm{ml}$ falcon tubes. Pellets were suspended in $0.85 \% \mathrm{NaCl}$ and the optical density of the cultures was adjusted to $1.0 \mathrm{OD}(620 \mathrm{~nm})$. Then, bacterial suspension $(1.5 \mathrm{ml})$, carbon source (crude oil, $100 \mu \mathrm{l}$ and $20 \mathrm{mM}$; nutrient broth as control) and metal solution ( $0.5 \mathrm{ml}$ of arsenate and arsenite) were transferred into $50 \mathrm{ml}$ sterile Falcon tubes followed by the addition of triphenyltetrazolium chloride (TTC) solution (5 ml) solution, contents mixed well and incubated shaking (200 rpm) at $30^{\circ} \mathrm{C}$ for 24 hours. Solution of TTC was prepared by dissolving $0.1 \mathrm{~g}$ TTC in $100 \mathrm{ml}$ $100 \mathrm{mM}$ Tris $\mathrm{HCl}$ buffer ( $\mathrm{pH}$ 7.6). Following incubation, the reduction product of TTC, triphenyl formazan (TPF), was extracted with acetone (40 ml) by agitation in the dark. The extracts were membrane filtered $(0.45 \mathrm{~mm})$ and the presence of the red-coloured TPF was detected in the filtrate by a spectrophotometer (Genesis 5) at $546 \mathrm{~nm}$. Concentration of formed TPF was determined using TPF calibration curve.

\subsubsection{Mineralization of crude oil}

The effects of the addition of different concentrations of arsenate (5, 10 and $\left.20 \mathrm{mg}^{-1} \mathrm{ml}\right)$ and arsenite $\left(0.6\right.$, and $\left.1.2 \mathrm{mg}^{-1} \mathrm{ml}\right)$ in on the utilization of crude oil by crude oil-degrading bacteria were determined using respirometry. The amounts of carbon dioxide evolved were measured using a Micro-oxymax respirometer (Columbus Instruments, USA). The reaction vessels contained $1 \mathrm{ml}$ of overnight bacterial cultures with optical density adjusted to $1.0(600 \mathrm{~nm})$ as mentioned previously, Hutner's minimal media (45 ml), crude oil $(100 \mu \mathrm{l})$, and 
desired metal concentration (4 ml). Reaction vessels were incubated in a shaking water bath at $30^{\circ} \mathrm{C}$ for 24 hours. Three sets of controls were used. One set of controls constituted vessels contained sterile Hutner's minimal media and crude oil. Another set of controls included vessels contained Hutner's minimal media, crude oil and bacterial cultures. In addition, one set of controls constituted vessels contained sterile Hutner's minimal media and bacterial cultures. The amounts of evolved carbon dioxide determined were used as indicator of bacterial activity.

\subsection{Fingerprinting of the CODB Acinetobacter spp. and Nocardia spp. using restriction fragment length polymorphism (RFLP) of 16S rRNA}

Sequences of 16S rDNA genes of the CODB Acinetobacter spp. and Nocardia spp. strains were amplified from extracted DNA. Following PCR amplification, $10 \mu \mathrm{l}$ of amplified 16S rDNA from each of isolates were digested separately with $B s t U I$ restriction endonuclease (New England Biolabs) in $15 \mu$ reaction mixtures as recommended by the manufacturer. Digests were electrophoresed in $2 \%$ agarose gels, with TBE buffer. Gels were stained with ethidium bromide and then photographed under UV light. DNA fragment sizes were determined using Kodak Digital Image analysis software (Kodak, Rochester). The quality of the numerical data was checked by comparing the sum of fragment sizes in each restriction pattern with the original product size (approximately 1,499 bp). Cluster analyses of band patterns were carried out using GelCompar II software (Applied Maths). Profiles of isolated bacteria were compared based on Pearson coefficient with an optimization of $1.0 \%$ and a tolerance of $1.0 \%$. Dendrograms were obtained using the hierarchical Dice correlation/unweighted pair group method with arithmetic mean (UPGMA) algorithm. Fragments smaller than 48.5 bp in length were not used in the analyses [19]. Each phylotype was defined as a group of sequences that have indistinguishable BstUI restriction patterns [20].

\section{Results}

\subsection{1 Effects of Arsenic compounds on the growth of the CODB Acinetobacter spp. and Nocardia spp.}

The effects of arsenate and arsenite on the growth of Acinetobacter spp. and Nocardia spp. strains were determined by the well diffusion method and by optical density measurements (Tables 1-3). Based on the values of diameter of inhibition zones, it was considered convenient to group the tested bacteria into three groups (Table 1). All tested bacteria showed zone of inhibition of $\leq 0.5 \mathrm{~cm}$ when reacted with arsenate. On the other hand, 38.1\%, $19 \%$ and $42 \%$ of tested Acinetobacter strains showed zones of inhibition of $0.5,>0.5<1$, and $\geq 1 \mathrm{~cm}$, respectively, also, $55.6 \%$ and $44.4 \%$ of tested Nocardia spp. showed zones of inhibition of 0.5 and $>0.5<1$ when reacted with arsenite (Table 1). Moreover the MIC values of arsenic compounds determined from the optical density 
measurements showed the varying reactions of tested bacteria against arsenic compounds (Tables 2). Higher MIC value was recorded for arsenate (30 mg ml${ }^{-1}$ ) compared to arsenite $\left(1.5 \mathrm{mg} \mathrm{ml}^{-1}\right)$ among Acinetobacter spp. and Nocardia spp. strains, respectively.

Table 1: $\quad$ Effects of arsenate and arsenite on the growth of Acinetobacter spp. and Nocardia spp.

\begin{tabular}{|c|c|c|c|c|}
\hline \multirow{2}{*}{ Bacteria } & \multirow{2}{*}{$\begin{array}{c}\text { Number of tested } \\
\text { bacteria }\end{array}$} & \multicolumn{3}{|c|}{ Inhibition zone $(\mathrm{cm})$} \\
\hline & & $\leq 0.5$ & $>0.5<1$ & $\geq 1$ \\
\hline \multicolumn{5}{|l|}{ Arsenate $\left(\mathrm{As}^{+5}\right)$} \\
\hline Acinetobacter spp. & 24 & 24 & Nil & Nil \\
\hline Nocardia ssp. & 34 & 34 & Nil & Nil \\
\hline \multicolumn{5}{|l|}{ Arsenite $\left(\mathrm{As}^{+3}\right)$} \\
\hline Acinetobacter spp. & 42 & 16 & 8 & 18 \\
\hline Nocardia ssp. & 27 & 15 & 12 & Nil \\
\hline
\end{tabular}

Table 2: $\quad$ MIC values of arsenate and arsenite of Acinetobacter spp. and Nocardia spp.

\begin{tabular}{|c|c|c|c|}
\hline \multirow{2}{*}{$\begin{array}{c}\text { Serial } \\
\text { No. }\end{array}$} & \multirow{2}{*}{ Bacteria } & \multicolumn{2}{|c|}{ MIC (mg ml-1) } \\
\hline & & Arsenate & Arsenite \\
\hline 1 & Acinetobacter schindleri & Nil* & 1.5 \\
\hline 2 & Acinetobacter schindleri & 30 & 1.5 \\
\hline 3 & Acinetobacter schindleri & 30 & 1.5 \\
\hline 4 & Acinetobacter schindleri & Nil* & 1.5 \\
\hline 5 & Nocardia cummidelens & 30 & 1.5 \\
\hline 6 & Nocardia fluminea & Nil* & Nil* \\
\hline 7 & Nocardia ignorata & Nil* & 1.5 \\
\hline 8 & Nocardia ignorata & Nil* & 1.5 \\
\hline 9 & Nocardia sp. & 30 & 1.5 \\
\hline 10 & Nocardia sp. & 30 & Nil* \\
\hline 11 & Nocardia sp. & 30 & 1.5 \\
\hline 12 & Nocardia cummidelens & $\mathrm{Nil}^{*}$ & 1.5 \\
\hline 13 & Nocardia cummidelens & $\mathrm{Nil}^{*}$ & Nil* \\
\hline 14 & Nocardia sp. & Nil* & 0.15 \\
\hline
\end{tabular}

*No MIC values were determined due to the ability of bacteria to grow at high concentrations of the arsenic compounds. 
In addition, the abilities of these bacterial strains to grow at high concentrations of arsenic compounds were used to demonstrate the arsenic resistance phenotypes (Table 3). Results revealed that while $50 \%$ of Acinetobacter spp. strains showed resistance to arsenate, none of them were resistant to arsenite. In contrast, $60 \%$ and $30 \%$ of Nocardia spp. strains showed resistance to arsenate and arsenite respectively. Also, 20\% of Nocardia spp. strains demonstrated resistance against both arsenate and arsenite (Table 3).

Table 3: $\quad$ Resistance phenotypes of Acinetobacter spp. and Nocardia spp. reacted with arsenic compounds.

\begin{tabular}{|c|c|c|}
\hline Serial No. & Bacteria & Resistant \\
\hline 1 & Acinetobacter schindleri & $\mathrm{As}^{+5}$ \\
\hline 2 & Acinetobacter schindleri & Nil* \\
\hline 3 & Acinetobacter schindleri & Nil* \\
\hline 4 & Acinetobacter schindleri & $\mathrm{As}^{+5}$ \\
\hline 5 & Nocardia cummidelens & Nil* \\
\hline 6 & Nocardia fluminea & $\mathrm{As}^{+5} / \mathrm{As}^{+3}$ \\
\hline 7 & Nocardia ignorata & $\mathrm{As}^{+5}$ \\
\hline 8 & Nocardia ignorata & $\mathrm{As}^{+5}$ \\
\hline 9 & Nocardia sp. & Nil* \\
\hline 10 & Nocardia sp. & $\mathrm{As}^{+3}$ \\
\hline 11 & Nocardia sp. & Nil* \\
\hline 12 & Nocardia cummidelens & $\mathrm{As}^{+5}$ \\
\hline 13 & Nocardia cummidelens & $\mathrm{As}^{+5} / \mathrm{As}^{+3}$ \\
\hline 14 & Nocardia sp. & $\mathrm{As}^{+5}$ \\
\hline
\end{tabular}

*No phenotypes were determined due to the un-ability of bacteria to grow at high concentrations of arsenic compounds.

\subsection{Effects of arsenic compounds on the dehydrogenase activity of isolated strains of Acinetobacter spp. and Nocardia spp.}

The affects of arsenate and arsenite on the dehydrogenase activity in the presence of crude oil were investigated. Both Acinetobacter spp. and Nocardia spp. strains showed significantly low dehydrogenase activity when supplied with crude oil compared to that of nutrient broth. Moreover the dehydrogenase activity of tested strains was more labile to arsenite compared to that in the presence of arsenate (Table 4).

\subsection{Effects of arsenate and arsenite on crude oil mineralization by the Acinetobacter spp. and Nocardia spp.}

Crude oil mineralization was determined by respirometry. Higher amounts of crude oil mineralization were determined for Nocardia spp. strains compared to that of Acinetobacter spp. strains (Table 5). 
Table 4: $\quad$ Effects of arsenate and arsenite on the dehydrogenase activity of Acinetobacter spp. and Nocardia ssp. bacteria supplied with crude oil.

\begin{tabular}{|c|c|c|c|c|c|c|}
\hline Bacteria & \multicolumn{3}{|c|}{ Nutrient Broth (Control) } & \multicolumn{3}{|c|}{ Crude oil } \\
\hline Arsenate $\left(\mathrm{mg} \mathrm{ml}^{-1}\right)$ & 5 & 10 & 20 & 5 & 10 & 20 \\
\hline Acinetobacter spp. & $96-3.8$ & $91-1.7$ & $83.3-0.64$ & $33.3-0$ & $25-0$ & $5.5-0$ \\
\hline Nocardia spp. & $82-7.5$ & $78-3.3$ & $62-2.1$ & $96-60$ & $91-40$ & $79-5$ \\
\hline Arsenite (mg ml ${ }^{-1}$ ) & 0.6 & & 1.2 & 0.6 & & 1.2 \\
\hline Acinetobacter spp. & $66.6-0.5$ & & $50.8-0.2$ & $25-0$ & & $20-0$ \\
\hline Nocardia spp. & $62-31$ & & $60-26$ & $67-30$ & & $51-25$ \\
\hline
\end{tabular}

Table 5: Effects of arsenate and arsenite on crude oil mineralization by Acinetobacter spp. and Nocardia spp. bacteria.

\begin{tabular}{|l|c|c|c|c|c|}
\hline \multirow{2}{*}{ Bacteria } & \multicolumn{4}{|c|}{ Arsenic compounds (mg ml $\left.\mathbf{~}^{\mathbf{1}}\right)$} \\
\cline { 2 - 6 } & \multicolumn{4}{|c|}{ Arsenate $\left(\mathrm{As}^{+5}\right)$} & \multicolumn{2}{c|}{ Arsenite $\left(\mathrm{As}^{+3}\right)$} \\
\cline { 2 - 6 } & 5 & 10 & 20 & 0.6 & 1.2 \\
\hline & \multicolumn{4}{|c|}{ Amount of carbon dioxide evolved (\%) } \\
\hline Acinetobacter spp. & 60 & 55.6 & 5.8 & 68.3 & 6.6 \\
\hline Nocardia spp. & 98 & 64.9 & 9.3 & 8.2 & 68.5 \\
\hline
\end{tabular}

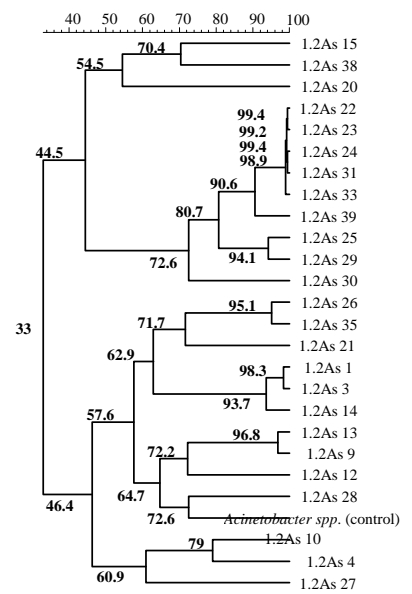

Figure 1: Dendrogram constructed by UPGMA cluster analysis of similarity coefficients derived from RFLP analysis of 16S rDNA of crude oildegrading Acinetobacter spp., isolated from soil amended with arsenite $\left(1.2 \mathrm{mg}^{-1} \mathrm{ml}\right)$ obtained with BstUI restriction enzyme. The levels of linkage representing the Dice correlation/UPGMA are expressed as percentages shown at each node. 


\subsection{Phylogenetic analysis of the CODB strains of Acinetobacter spp. and Nocardia spp. by RFLP}

In order to evaluate the diversity of the Acinetobacter spp. and Nocardia spp. in the presence of arsenic compounds, the 16S rDNA sequences of different strains isolated from soil amended with $1.2 \mathrm{mg} \mathrm{ml}^{-1}$ of arsenite were compared using the 16S-RFLP method. The assessment of the diversity of the Nocardia isolates by 16S-RFLP analysis demonstrated the presence of sixteen different phylogroups at similarity coefficient of $90 \%$ (Figure 2). Moreover, four different species belonging to the genus Nocardia were identified. On the other hand, 16SRFLP analyses of Acinetobacter isolates showed the presence of fifteen different phylogroups at similarity coefficient of $90 \%$ (Figure 1 ). Also only two different species belonging to the genus Acinetobacter were identified.

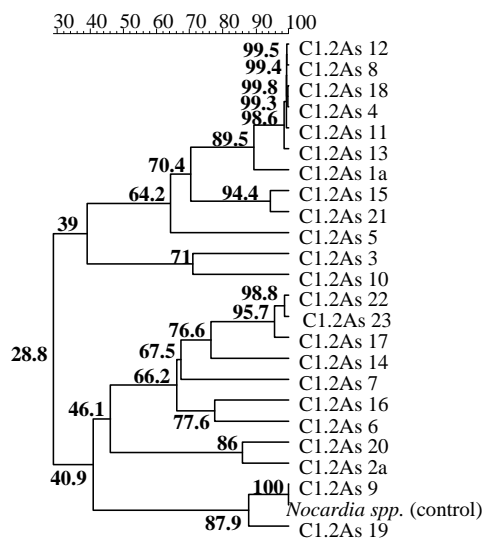

Figure 2: Dendrogram constructed by UPGMA cluster analysis of similarity coefficients derived from RFLP analysis of 16S rDNA of crude oildegrading Nocardia spp., isolated from soil amended with arsenite $\left(1.2 \mathrm{mg}^{-1} \mathrm{ml}\right)$ obtained with BstUI restriction enzyme. The levels of linkage representing the Dice correlation/UPGMA are expressed as percentages shown at each node.

\section{Discussion}

Differences in bacteria growth determined by well diffusion method were insignificant in the presence of arsenate which could be due to nature of the method or the potential of bacterial biofilms to resist heavy metals [21]. However, the addition of arsenite showed significant differences in bacterial growth (Table 1). This indicated the higher potentials of arsenite to inhibit bacterial growth which was further investigated by the optical-density measurement experiments that confirmed previous results (Tables 2 and 3). In 
addition, higher MIC values were recorded for arsenate (30 $\mathrm{mg} \mathrm{ml}^{-1}$ ) compared to arsenite $\left(1.5 \mathrm{mg} \mathrm{ml}^{-1}\right)$. Thus, based on well diffusion and optical density measurement experiments, it was concluded that arsenite possessed higher toxicity on bacterial growth compared to arsenate which was in agreement with previous studies [22, 23]. The effects of arsenic compounds on bacterial activity were further studied and results showed the higher inhibitory effects of arsenite on bacterial dehydrogenase activity compared to that of arsenate (Table 4). Also, the higher dehydrogenase activity determined in the presence of nutrient broth compared to that in the presence of crude oil indicated the bacterial preference to nutrient broth over that to crude oil. These results were in agreement with previous reports indicating that crude oil is typically non-preferred substrates for bacteria [24]. Furthermore, higher crude oil mineralization determined for the Gram-positive bacterium Nocardia spp. compared to that of the Acinetobacter spp. a Gram-negative bacterium. The potential of these bacteria to degrade hydrocarbons was documented previously [25-28] and have been isolated previously from Kuwait environment [13-16]. Thus, it was unsurprising to isolate them from crude oil-contaminated soils in Kuwait. Moreover, 16S-RFLP analyses showed the higher diversity of Nocardia spp. compared to Acinetobacter spp. strains which reflected the high adaptable nature of Nocardia spp. to the harsh environment of contaminated sites in Kuwait harboring high concentrations of hydrocarbons and heavy metals that reduced the diversity of less adaptable strains of Acinetobacter spp. These finding were in agreement with previous reports demonstrating the effects of hydrocarbons and heavy metals on bacterial diversity in soil [29, 30].

\section{Conclusions}

The bioremediation of crude oil in soil is a complex process that is affected by several factors explicitly the characteristics of soil indigenous microbiota and chemical composition of soil. Thus the assessment of the effects of arsenic compounds on crude oil bioremediation in soil for the predominant CODB in Kuwait Acinetobacter spp. a Gram-negative bacterium and Nocardia spp. a Gram-positive bacterium were determined. The potential inhibitory effects of arsenic compound on bacterial growth and activities showed higher toxicity of arsenite over that of arsenate. Moreover it was concluded that Nocardia spp. strains possessed higher adaptation potentials to the presence of arsenic compounds and crude oil compared to Acinetobacter spp. strains which most probably affected their diversity in soil. The current study was one of the first efforts to investigate the effects of arsenic compounds on soil microbiota in Kuwait, thus, more studies are required on more soil samples from other areas of Kuwait to investigate effects of arsenic compounds on crude oil bioremediation.

\section{Acknowledgements}

We would like to acknowledge the Research Administration and College of Graduated Studies in Kuwait University for funding this project. The efforts of 
the sequencing facility of the Biotechnology Center in Kuwait University are highly appreciated.

\section{References}

[1] Zarba, M. A., Mohammad, O. S., Anderlini, V. C., Literathy, P. and Shunbo, F. Petroleum residues in surface sediments of Kuwait. Marine Pollution Bulletin, 16(5), 209-211, 1985.

[2] Mahmoud, F. F., Al-Harbi, S. A., McCabe, M., Haines, D. D., Burleson, J. A. and Kreutzer, D. L. Abnormal lymphocyte surface antigen expression in peripheral blood of a Kuwaiti population. Annals of the New York Academy of Sciences, 793(1), 498-503, 1996.

[3] Durako, M. J., Kenworthy, W. J., Fatemy, S. M. R., Valavi, H. and Thayer, G. W. Assessment of the toxicity of Kuwait crude oil on the photosynthesis and respiration of seagrasses of the northern Gulf. Marine Pollution Bulletin, 27(2), 223-227, 1993.

[4] Obuekwe, C. O. and Al-Zarban, S. S. Bioremediation of crude oil pollution in Kuwaiti Dessert: the role of adherent microorganisms. Environment international, 24(8), 823-834, 1998.

[5] Shen, G., Y. Lu and J. Hong. Combined effect of heavy metals and polycyclic aromatic hydrocarbons on urease activity in soil. Ecotoxicology and environmental safety, 63(3), 474-480, 2006.

[6] Christensen, L. H. and Agerbo, A. Determination of sulfur and heavy metals in crude oil and petroleum products by energy-dispersive X-ray fluorescence spectrometry and fundamental parameter approach. Analytical Chemistry, 53(12), 1788-1792, 1981.

[7] Puri, B. K. and Irgolic, K. J. Determination of arsenic in crude petroleum and liquid hydrocarbons. Environmental Geochemistry and Health, 11(3-4), 95-99, 1989.

[8] Stigter, J. B., De Haan, H. P. M., Guicherit, R., Dekkers, C. P. A. and Daane, M. L. Determination of cadmium, zinc, copper, chromium and arsenic in crude oil cargoes. Environmental Pollution, 107(3), 451-64, 2000.

[9] Matera, V. and Hecho, I. L. Arsenic behavior in contaminated soils: mobility and speciation. Lewis Publishers: Washington, DC, 2001.

[10] Hughes, M. F. Arsenic toxicity and potential mechanisms of action. Toxicology letters, 13(1), 1-16, 2002.

[11] Tsai, S. L., Singh, S., and Chen, W. Arsenic metabolism by microbes in nature and the impact on arsenic remediation. Current opinion in biotechnology, 20(6), 659-667, 2009.

[12] Gogolev, A. and Wilke, B. M. Combination effects of heavy metals and fluoranthene on soil bacteria. Biology and fertility of soils, 25(3), 274-278, 1997.

[13] AL-Saleh, E., Drobiova, H. and Obuekwe, C. (2009). Predominant culturable crude oil-degrading bacteria in the cost of Kuwait. Inter. Biodeg. Biodeter., 63: 400-406. 
[14] Radwan, S. S., Al-Hasan, R. H., Al-Awadhi, H., Salamah, S. and Abdullah, H. M. Higher oil biodegradation potential at the Arabian Gulf coast than in the water body. Marine Biology, 135(4), 741-745, 1999.

[15] Sarkhoh, N. A., Ghannoum, M. A., Ibrahim, A. S., Stretton, R. J. and Radwan, S. S. Crude oil and hydrocarbon degrading strains of Rhodococcus: Rhodococcus strains isolated from soil and marine environments in Kuwait. Environmental Pollution, 65(1), 1-17, 1990.

[16] Khan, Z. U., Neil, R., Chandy, T. D., Al-Sayer, H., Provost, F. and Boiron, P. Nocardia asteroides in the soil of Kuwait. Mycopathologia, 137(3), 159163, 1997.

[17] Lertcanawanichakul, M. and Sawangnop, S. A comparison of two methods used for measuring the antagonistic activity of Bacillus species. Walailak Journal of Science and Technology, 5(2), 161-171, 2008.

[18] Alef, K. Dehydrogenase activity. Academic Press, Inc: London, 1995.

[19] Tenover, F. C., Arbit, R. D., Goering, R. V., Mickelsen, P. A., Murray, B. E., Persing, D. H. and Swaminathan, B. Interpreting chromosomal DNA restriction patterns produced by pulsed-field gel electrophoresis: criteria for bacterial strain typing. Journal of clinical Microbiology, 33(9), 2233-2239, 1995.

[20] Dunbar, D., Wormsley, S., Lowe, T. and Baserga, S. Fibrillarin-associated box C/D snoRNAs in Trypanosoma brucei: sequence conservation and implication for 2'-O-ribose methylation of rRNA. The Journal of Biological Chemistry, 65(16), 1662-1669, 1999.

[21] Jackson, C. R., Harrison, K. G. and Dugas, S. L. Enumeration and characterization of culturable arsenate resistant bacteria in a large estuary. Systematic and Applied Microbiology, 28(8), 727-734, 2005.

[22] Turpeinen, R., Kairesalo, T. and Haeggblom, M. M. Microbial community structure and activity in arsenic, chromium, and copper contaminated soils. FEMS microbiology Ecology, 47(1), 39-50, 2004.

[23] Achour, A. R., Bauda, P. and Billard, P. Diversity of arsenite transporter genes from arsenic-resistant soil bacteria. Research in microbiology, 158(2), 128-137, 2007.

[24] Ma, D., D. N. Cook, J. E. Hearst, and H. Nikaido. Efflux pumps and drug resistance in Gram-negative bacteria. Trends in Microbiology. 2(12), 489493, 1994.

[25] Ramos, J. L., Duque, E., Gallegos, M. T., Godoy, P., Ramos-Gonzalez, M. I., Rojas, N., Terán, W. and Segura, A. Mechanisms of solvent tolerance in gram-negative bacteria. Annual Review of Microbiology, 56(7), 743-68, 2002.

[26] Hanson, K. G., Nigam, A., Kapadia, M. and Desai, A. Bioremediation of crude oil contamination with Acinetobacter sp. A3. Current Microbiology, 35(3), 191-193, 1997.

[27] Davis, J. B. and Raymond, R. L. Oxidation of alkyl-substituted cyclic hydrocarbons by a Nocardia during growth on $n$ - alkanes. Applied Microbiology, 9(5), 383-388, 1961. 
[28] Gebhardt, H., Meniche, X., Tropis, M., Krämer, R., Daffe, M. and Morbach, S. The key role of the mycolic acid content in the functionality of the cell wall permeability barrier in Corynebacterineae. Microbiology. 153(5), 1424-34, 2007.

[29] Juck, D., Charles, T., Whyte, L. G. and Greer, C. W. Polyphasic microbial community analysis of petroleum hydrocarbon-contaminated soils from two northern Canadian communities. FEMS Microbiology Ecology, 33(3), 241249, 2000.

[30] Kozdrój, J and Van Elsasb, J. D. Structural diversity of microorganisms in chemically perturbed soil assessed by molecular and cytochemical approaches. Journal of Microbiological Methods, 43(3), 197-212, 2001. 